\title{
Will the SUP be an Effective Legal Form for SMEs as Well as for Subsidiaries within the European Union?
}

\author{
Hylda Boschma
}

Professor of Company Law, Faculty of Law, University of Groningen h.e.boschma@rug.nl

Hanny Schutte-Veenstra

Professor of Corporate Law, Faculty of Law and the Faculty of Economics and Business, University of Groningen

j.n.schutte-veenstra@rug.nl

\begin{abstract}
In 2014, the Commission published a proposal for a Directive that introduces a singlemember private limited liability company, under a common label: Societas Unius Personae (SUP), into the national legislation of the EU-Member States. In this publication it is examined what kind of legal forms of capital companies already exist in the EU-Member States and whether the SUP is a welcome addition. The proposed legal form of the SUP is analysed in order to answer the question whether the SUP is an appropriate legal form for SMEs and subsidiaries. Furthermore attention is paid to issues which generally arise when the European legislator attempts to introduce a new legal enterprise-form, such as the sup. The authors conclude that there are no irreconcilable differences between the laws of the EU-Member States that might hinder the introduction of the sUP. Also the European principles of subsidiarity and proportionality will not constitute an obstacle.
\end{abstract}

\section{Keywords}

European Union - new legal enterprise-forms - private company - sUP - Directive

(C) BOSCHMA AND SCHUTTE-VEENSTRA, 2017 | DOI 10.1163/22134514-00403004

This is an open access article distributed under the terms of the prevailing CC-BY-NC license at the time of publication. 


\section{Introduction}

On 9 April 2014, the European Commission published a proposal for a Directive that introduces a single-member private limited liability company, under a common label: Societas Unius Personae (SUP), into the national legislation of the European Union (EU) Member States; the draft SUP Directive, based on Article 50(2)(f) TFEU. ${ }^{1}$ At its meeting on 28 May 2015, the Competitiveness Council reached a general approach. ${ }^{2}$ The compromise text differs on a number of points from the former proposal presented by the Commission (see section 3.3.). In this publication, references to the draft sup Directive concern the compromise text.

A brief introduction to sups shows that they are private limited liability companies with a single member, meaning that their single share is held by a single person. An SUP has full legal personality. Both natural persons and legal persons (of all sizes) have the opportunity to incorporate an SUP. An SUP can be incorporated ex nihilo or through conversion. The incorporation and registration of an SUP is simplified; the entire process is digital in nature. There is no need for the founder to appear physically before any authority in the Member State of registration. Furthermore, the incorporation of an SUP is achieved by a minimum capital requirement of EUR 1 .

The main objective of the Commission's proposal is to make it easier and less costly to set up companies across the EU. Also, cross border groups are facilitated. In the words of the Commission: ${ }^{3}$

In particular, it aims to encourage SMEs, including individual entrepreneurs, to carry out their activities in other Member States. At the same time, it should also benefit groups consisting of sMEs and larger companies by allowing them to set up single-member subsidiaries according to the same main requirements across the $\mathrm{EU}^{4}$

1 'Proposal for a Directive of the European Parliament and of the Council on single-member private limited liability companies' Сом(2014) 212 final (2014 April).

2 European Council 29 May 2015 9050/15 DRS 41 CODEC 751.

3 Memo European Commission, 'Proposal for a Directive on single-member private limited liability companies - frequently asked questions', 9 April 2014, 2.

4 Its particular focus is on subsidiaries (i.e. companies in which another company holds all or parts of the shares or a majority of the voting rights, or has the right to appoint/remove a majority of the board members, or over which another company has the right to exercise a dominant influence), as this is the most frequently chosen legal form of establishment abroad. 
The objective of this publication is to examine whether the SUP is an appropriate legal form for Small and Medium Sized Enterprises (SMEs) as well as for subsidiaries within the European Union. Furthermore, we will look into the issues which more generally arise when the European legislator attempts to introduce a new legal enterprise form, in this case focusing on the forthcoming SUP.

In order to answer these questions, the following themes will be dealt with. First of all: what are the current available legal forms for enterprises in the $\mathrm{EU}$ ? This question will be addressed in section 2. The focus will be on so-called 'capital companies'. Not only will national legal forms be examined but also supra-national European legal forms. Special attention will be given to the already existing EU-legislation on single-member companies. The second theme includes an analysis of the proposed legal form of the SUP. This analysis, as well as the pros and cons of the SUP, are described in section 3 . Then, we shift the focus to some disintegrating influences between Member States which (might) hinder the introduction and/or development envisaged by the European legislator of a new legal enterprise form such as the SUP. We describe these influences in section 4. Finally, we pay attention to a number of European issues such as the choice of the legal basis for the SUP and the principles of subsidiarity and proportionality (section 5 ). Some concluding remarks are made in section 6 .

\section{Current Available Legal Forms for Enterprises in the EU}

\subsection{Introduction}

In this publication we will focus on legal forms of limited liability companies with a capital structure as this is the form of company most often used by SMEs especially in setting up subsidiaries or a group of subsidiaries abroad. ${ }^{5}$ In all Member States a distinction is made between two types of capital companies: private companies and public companies. The coming into existence of both types has been an autonomous development in the Member States independent of the EU harmonisation programme. However, as a direct result

5 Therefore (civil) partnerships (frequently used by smes and in groups) and sole traders fall outside the scope of this publication; see Commission Staff Working Document, Impact Assessment, Accompanying the document 'Proposal for a directive of the European Parliament and of the Council on single-member private limited liability companies' $\operatorname{SWD}(2014) 124$ final (April 2014) para. 3.2. 
of the enactment of the First Company Law Directive ${ }^{6}$ in the Netherlands, the formerly unknown private company (besloten vennootschap (BV)) was introduced in order to escape the publication requirements imposed on the public company.

Each type of company (both public and private), is subject to a different set of rules at the national level. The European legislator also distinguishes between both types. Sometimes EU legislation exclusively applies to public companies (e.g. the Second Company Law Directive on capital protection ${ }^{7}$ ), whereas other EU legislation focuses on private companies (e.g. the Twelfth Company Law Directive on single-member companies ${ }^{8}$ ). Besides the national types of capital companies there is also an EU capital company: Societas Europaea (SE).

\subsection{National Legal Forms and the Extent of Harmonisation}

Public and private limited liability companies have legal personality as entities separate from their members. The characteristics of both types of capital companies differ among Member States. We will make some general remarks about the distinctions between public and private companies with the caution that there are a lot of exceptions. In order to meet the need for a more flexible and simple form of a capital company, some Member States amended their national company law recently and others introduced new legal forms. In the following we will discuss in general the characteristics of a public company, a private company, and finally of some simpler forms of capital companies, like the SAS in France and Luxembourg, the Spanish SLNE and the German UG.

\subsubsection{Public Companies}

A public company offers its securities (stock/shares, bonds/loans, etc.) for sale to the general public; hence the name public company. For that reason national law provides that the shares in a public company are freely transferable. This is also the reason that a public company may be used to gain access to the capital markets, i.e. to offer its securities for sale on the stock exchange.

6 Directive 68/151/EEC, which was codified by Directive 2009/101/EC of 16 September 2009 OJ L $258 / 11$.

7 Directive 77/91/EEC, which was codified by Directive 2012/30/EU of 25 October 2012 OJ L $315 / 74$.

8 Directive 89/667/EEC, which was codified by Directive 2009/102/EC of 16 September 2009 OJ L $258 / 20$. 
In MIFID ${ }^{9}$ terms: the securities are admitted to trading on a regulated market or a multilateral trading facility. Such a company is called a stock exchange company or a listed company. However, the free transferability of a public company's shares is not a necessary element: national law may provide for the imposition of restrictions on the transfer of the securities of a public company, as is the case in Germany and the Netherlands. ${ }^{10}$ In both Member States the articles of association of a public company may make the transfer of its securities subject to the consent of a company body. Another possibility is that the articles of association provide that a shareholder, who wants to dispose of one or more of his shares, must offer those shares first of all to his co-shareholders or to a third party to be appointed by a company body (a pre-emption clause).

In a significant number of Member States a public company may choose between a one-tier and a two-tier board structure. ${ }^{11} \mathrm{~A}$ one-tier board structure or unitary board structure means that the company only has a management board with managers and supervisors (also called executive and non-executive directors). When a public company has opted for a two-tier board structure this company has two distinct boards: an executive board for the day-to-day management and a supervisory board with purely supervisory functions. However, in Austria, the Czech Republic, Estonia, Germany, Latvia, Poland and Slovakia the two-tier board structure is mandatory, whereas in Cyprus, Greece, Ireland, Malta, Spain and the United Kingdom only the one-tier board structure is available to public companies. ${ }^{12}$

A public company is frequently used by large enterprises and may have a large number of shareholders. Yet, this type is also used by relatively small businesses and may have a small number of shareholders accordingly. Generally speaking, public companies are less frequently used than private companies.

Directive 2004/39/EC of the European Parliament and of the Council of 21 April 2004 on markets in financial instruments amending Council Directives 85/611/EEC and 93/6/EEC and Directive 2000/12/EC of the European Parliament and of the Council and repealing Council Directive 93/22/EEC, OJ L 145/1. The MIFID-Directive has been amended several times.

10 Germany: Section. 68(2) AktG; the Netherlands: Article 2:87 DCC.

11 In the Scandinavian countries: Sweden, Denmark and Finland, the board structure of capital companies can best be described as a hybrid form, incorporating elements of both the one-tier and the two-tier system. It is called the 'Nordic Model'. See C. Gerner-Beuerle, P. Paech and E.P. Schuster, Study on Directors' Duties and Liability prepared for the European Commission DG Markt, Department of Law, London School of Economics, London April 2013, 7. 


\subsubsection{Private Companies}

A private company's shares are offered and traded privately. In a lot of Member States a notarial deed is required for the transfer of the shares; e.g. in Germany, the Netherlands and Spain. ${ }^{13}$ In general there is no access to public funding, hence shares of a private company may not be listed and traded on a stock exchange. ${ }^{14}$ Also, a private company's shares must be in registered form; the issue of shares in bearer form and/or bearer shares certificates is prohibited. ${ }^{15}$

In general, national law provides for more or less severe restrictions on the transfer of the shares of a private company, e.g. in Belgium, France and Spain. ${ }^{16}$ In the United Kingdom and Germany there are no mandatory restrictions placed on the transferability of a private company's shares. However, such restrictions generally appear in the articles of association of these companies. ${ }^{17}$ Moreover, Dutch law allows for a provision in the articles of association for a free transfer of shares. ${ }^{18}$

National laws on private companies allow for a substantial scope of private agreement, especially in respect of the structure of the company. In comparison

13 Germany: Section. 15(3) GmbHG; the Netherlands: Article 2:196 DCC; Spain: Article 106(1) 1/2010 Act.

14 UK law explicitly forbids this in Section 755 CA 2006. According to Article 1841 CC a French SARL is not entitled to issue securities to the public. In Italy the shares in a private company may not be offered for public subscription; Article 2468(1) CC. As an exception to this general rule in May 2016 the depository receipts of the Dutch Fastned BV were listed on the regulated market of Nx'change.

15 E.g. France: Article L 223-12; the Netherlands: Article 2:175(1) DCC; Spain: Article 92(2) $1 / 2010$ Act.

16 Belgium: Articles 249-254 BCC provide that a member cannot transfer its shares to a third party who is not a member of the SARL without the consent of at least half of the other members, who must possess at least three-quarters of the remaining shares. The articles of association cannot contain less stringent conditions. France: the transfer of the shares of an SARL must be approved by the majority of the shareholders holding at least one half of the SARL's capital (Article L 223-14). The approval is compulsory in the case of a transfer to third parties who are not members of the SARL. It is optional to transfer shares to other members or to certain relatives, unless the articles of association provide otherwise (Article L 223-16). In Spain Articles 107-1121/2010 Act impose substantial restrictions on the transfer of shares to third parties who are not members of the Sociedad de Responsabilidad Limitada (SL).

17 The United Kingdom: Section 544(1) CA 2006; Germany: Sections. 15(1) and (5) GmbHG. Placing restrictions on the transferability of $\mathrm{GmbH}$ shares is called 'Vinkulierung'. See M. Schulz and O. Wasmeier, The Law of Business Organizations: A Concise Overview of German Corporate Law (Berlin Heidelberg: Springer-Verlag, 2012) 108.

18 Article 2:195(1) DCC. 
with a public company, more rules are default rules; deviations of the general rules are possible in the articles of association. Also, the rules in respect of a private company are often more liberal than the ones applicable to a public company. An example of this is that, in the United Kingdom and the Netherlands, for instance, a private company is not required to hold an annual general meeting; the law grants private companies the facility of passing a resolution that is recorded in writing or electronically. ${ }^{19}$

A private company is frequently used by sMEs. However, even large businesses may take the form of a private company. Generally speaking, a private company is owned by a relatively small number of members. ${ }^{20}$ Finally, it should be mentioned that a private company is the most popular organizational form for business in the EU Member States. ${ }^{21}$

\subsubsection{Simplified Forms of Capital Companies}

Some Member States have introduced simplified forms of a capital company besides the general forms of public and - sometimes recently made more flexible - private companies, such as the French SAS, the Spanish SNLE and the German U G. ${ }^{22}$

19 See the United Kingdom: Section 755 CA 2006 and the Netherlands: Article 2:238 Dcc. In France the annual accounts are subject to approval by the general meeting (Article L 223-26 al. 1). The articles of association of an SARL may nevertheless stipulate that in respect of subjects other than the annual accounts, all or certain decisions may be taken via a written consultation of the shareholders or may result from the consent of all the shareholders expressed in an act (Article L 223-27 al. 1).

20 Generally, there are no legal provisions stipulating a maximum number of shareholders. However in France Article L 223-2 provides that the number of shareholders of an SARL shall not exceed 100. The same number applies to a Luxembourg SARL, since the new companies' law was adopted by parliament on 13 July 2016 (Bill of law 5730, modernizing the law on commercial companies of 10 August 1915).

21 The use that is made of public and private companies differs considerably between EU Member States. On the one hand, in Greece private companies are little used in comparison with public companies, while on the other hand, in the United Kingdom, Ireland, Germany, the Netherlands, Austria, Spain and Sweden private companies make up almost the entirety of the number of capital companies. See R. Drury, 'Why Do We Need The European Private Company (Societas Privata Europaea)?', in: H. Hirte and C. Teichmann (eds) European Company and Financial Law Review - Special Volume 3: The European Private Company - Societas Privata Europaea (SPE) (Berlin: Verlag Walter de Gruyter GmbH, 2012) 40.

22 These are not the only examples. In 2012, the Belgian legislator introduced a private limited liability company 'starter' (SPRL-S). Since 2012 the Italian legislator made available a simplified version of its private limited liability company (società a responsabilità 


\subsubsection{The French SAS}

In 1994 a simplified capital company was introduced in France, called la société par actions simplifiée (SAS). ${ }^{23}$ The legal framework of an SAS is much more flexible than that of a standard French public or private company. In principle the provisions in respect of the French SA are applicable to the sAs with the exception of some explicitly mentioned provisions, such as those concerning the management structures of the SA and its general meeting. ${ }^{24}$ Consequently, the founders of an SAS are free to determine the organizational structure of the sAs in its articles of association. ${ }^{25}$ The only obligation is to appoint a president who is responsible for managing the sAs. The president is also the only person authorised to act on behalf of the sAs with respect to third parties (representation of the SAS ). ${ }^{26}$ Besides the president, a general director ('directeur général') may be appointed with similar powers as those of the president. ${ }^{27}$ An sAs may also have ad hoc company bodies, such as a supervisory board, a remuneration committee or an audit committee. The articles of association may freely define the powers of these company bodies, subject to certain mandatory provisions regarding the powers of the president and those of the general meeting.

Also, the way in which the shareholders adopt decisions - modalities of consultation, quorum and majority of votes - can be determined freely in the articles of association of an sAs. ${ }^{28}$ Some decisions, however, e.g. the approval of the annual accounts and amendments to the share capital, must be taken collectively. ${ }^{29}$ Additionally, the rights and obligations of the shareholders of an sAs can be freely determined in the articles of association, subject to certain mandatory provisions. The liability of the shareholders, for instance, is limited to the amount they have contributed. ${ }^{30}$

limitata semplificata). In 2013, the Danish legislator introduced a Danish version of the German entrepreneurial company with limited liability, called ivaersaetterselskab (IVs). In addition, the Luxembourg legislator has recently (Law of August 2016) introduced the sAs into its legal system, following the French example.

23 Law 94-1 of 3 January 1994. See Y. Guyon, 'Présentation générale de la SAs', Revue des Sociétés (1994) 207.

24 See Article L 227-1 al. 3; the SA-provisions shall apply to the SAS, with the exception of Article L 224-2, L 225-17 to L 225-102-2, L 225-103 to L 225-126, L 225-243 and Article L 233-8 I.

25 See Article L 227-5.

26 See Article L 227-6 al. 1.

27 See Article L 227-6 al. 3 .

28 See Article L $227-9$ al. 1 .

29 See Article L 227-9 al. 2.

$30 \quad$ See Article L 227-1 al. 1. 
There is no minimum capital requirement, so the SAS can be incorporated with a capital of EUR $1 .{ }^{31}$ The share capital of an SAS must be paid up by at least $5^{0}$ percent at the time of incorporation; the unpaid part of the capital must be paid up within a maximum period of five years. ${ }^{32}$ The capital may be paid up in cash, in kind or in services. However, in the latter case these shares cannot be transferred. ${ }^{33}$ Shares of an SAS are normally freely transferable and negotiable unless the articles of association provide otherwise. The articles of association may provide that the transfer of shares is subject to a right of approval - to be granted by the president or by a decision of the shareholders with a specified majority or by another company body - or to other restrictions as specified in the articles of association. A pre-emption clause is possible: the seller first has to offer its shares to the other shareholders. Another possibility is an inalienability clause: a clause prohibiting shareholders to sell their shares during a period of up to ten years. ${ }^{34}$

An SAS may issue a variety of financial instruments, e.g. (convertible) bonds and warrants. The rights attached to shares may vary also; an SAS can issue preferred shares with multiple voting rights, preferential dividend rights and/orveto rights. Generally, an SAS may not offer its shares for sale to the general public. ${ }^{35}$ However, pursuant to an Order of 22 January 2009 the SAS is able to trade other securities besides shares on the capital market, for instance bonds, and can offer them to qualified investors. Thisnewfacilitymade thesas evenmore attractive. ${ }^{36}$

Finally, the SAS can be incorporated by one or more natural or legal persons. The fact that legal persons may be shareholders of an SAs makes the legal form useful in group structures. The sAs held by only one shareholder is called an SASU (société par actions simplifiée unipersonelle). The legal form of the SAS is often used in groups to organise wholly-owned subsidiary companies. Sometimes the parent company is a listed company, for example European aerospace giant Airbus, an SAS which is wholly owned by Airbus Group SE listed at the Frankfurt Stock Exchange. ${ }^{37}$ Other times the SAS is used as a subsidiary in

$3^{1} \quad$ See Article L 227-1 al. 3 pursuant to the Law of 4 August 2008.

32 See Article L 227-1 al. 3 jo. Article L 225-3 al. 2.

33 See Article L 227-1 al. 4.

34 See Article L 227-13.

35 See Article L 227-2 to L 227-2-1.

36 See Alliuriscompact (Alliance of International Business Lawyers), 2012. J.F. Chronowski and M. Heitmüller, 'The French simplified joint stock company (SAS)' Retrieved 29 June 2017 www.alliuris.com/fileadmin/herfurth/compact/AlliurisCompact_2012-04-SAS.pdf.

See the press release of 12 July 2001: 'EADS and BAE SYSTEMS complete Airbus integration - Airbus SAS formally established', Retrieved 10 July 2017 www.defense-aerospace. com/articles-view/release/3/5925/eads\%2C-bae-incorporate-airbus-(july-12).html. 
a group of companies held by one or more families. An example is the Louis Dreyfus Group, a French global conglomerate company, with its subsidiary Louis Dreyfus Commodities France SAs. ${ }^{38}$

\subsubsection{The Spanish SLNE}

The Spanish Sociedad Limitada Nueva Empresa (SLNE) was introduced by Law $7 / 2003$ of 1 April 2003. ${ }^{39}$ The SLNE is a special form of the Sociedad de Responsabilidad Limitada (SL) and cannot be considered a new type of company. The SNLE was intended to encourage the incorporation of new SMEs by making it simpler for them to set up a company and to do business within that legal form. ${ }^{40}$ An SNLE may be registered by means of a notarial deed of incorporation and an electronic document within 48 hours of execution of the notarial deed. ${ }^{41} \mathrm{~A}$ quicker incorporation is also stimulated by the fact that the founders of an SNLE can use a standard model of the articles of association. ${ }^{42}$

An SLNE also differs from an ordinary SL in respect of the permissible company name and the maximum number of shareholders. The company's name must comprise one of the founder's full names followed by a registration number and the abbreviation SLNE. ${ }^{43}$ The shareholders of an SLNE may only be natural persons and there is a maximum of five at the time of incorporation. ${ }^{44}$ Later on, the number of shareholders may be increased, however a shareholder may only be a sole shareholder in just one SLNE. 45

38 Louis Dreyfus Commodities France sas operates as a subsidiary of Louis Dreyfus Commodities BV. Information available online. Retrieved 10 July 2017 www.bloomberg.com/ research/stocks/private/snapshot.asp?privcapId= 5478032 .

39 Ley 7/2003, de 1 de abril, de la sociedad limitada Nueva Empresa. Retrieved 30 June 2017 www.circe.es. See F. Juan-Mateu, 'The Private Company in Spain - Some Recent Developments', European Company and Financial Law Review 1(1) (2004) 60-70. Nowadays the rules in respect of the SNLE can be found in the 1/2010 Act; the Royal Legislative Decree 1/2010 of 2 July 2010 approving the consolidated text of the corporate enterprises act (Ley de Sociedades de Capital (LSC)), Official State Journal (вов) No. 161, 3 July 2010.

40 World Business and Investment Library, Spain Company Laws and Regulations Handbook: Strategic Information and Basic Laws (USA: International Business Publications, 2012).

41 Article 439-441 1/2010 Act.

42 At the time the SNLE was introduced a standard model of the articles of association for an SNLE was provided for by an Order of the Ministry of Justice of 4 June 2003 containing the principal characteristics of an SNLE (Orden del Ministerio de Justicia 1445/2003, de 4 de junio, por la que se aprueban los Estatutos orientativos de la sociedad limitada Nueva Empresa). The text of this Order is available online. Retrieved 30 June 2017 www.circe.es. Article 435 1/2010 Act.

44 Article 437 1/2010 Act.

45 Article 438 1/2010 Act. 
The minimum capital of an SLNE is EUR 3,012. ${ }^{46}$ The minimum capital prescribed for the SL is EUR 3,000. ${ }^{47}$ Spanish law provides, in respect of an SLNE, for a maximum capital of EUR 120,202. Increasing the capital beyond this amount leads to a conversion into an SL. The shares of an SLNE can only be paid up in cash. ${ }^{48}$ Finally, the members of the SLNE's managing body must be shareholders. ${ }^{49}$

\subsubsection{The German UG}

On 1 November 2008 the 'Law for the Modernization of the GmbH and to combat its abuse' entered into force in Germany. ${ }^{50}$ This Act makes it possible to set up a special form of the $\mathrm{GmbH}$, the so-called Unternehmergesellschaft (UG) haftungsbeschränkt (entrepreneurial company with limited liability; hereafter UG ). ${ }^{51} \mathrm{~A}$ minimum capital of EUR 1 is required, ${ }^{52}$ whereas for a regular $\mathrm{GmbH}$ the minimum issued share capital is set at EUR $25,000 .^{53}$ The UG was introduced to improve the competitiveness of the $\mathrm{GmbH}$ especially in respect to the private limited liability company in the United Kingdom. The name of the entrepreneurial company should include the words 'Unternehmergesellschaft (haftungsbeschränkt)' or 'UG (haftungsbeschränkt)'. The idea behind this provision is that (potential) creditors are warned that they are not dealing with a regular $\mathrm{GmbH}$.

The UG is a special form of the $\mathrm{GmbH}$; i.e., the UG is not a separate legal form but a form of the GmbH. The provisions of the GmbH-Gesetz are applicable to an UG unless the Act provides otherwise. The difference in the figure of the minimum capital requirement is also the main distinguishing feature between the UG and the regular $\mathrm{GmbH}$.

\footnotetext{
46 Article 443(1) 1/2010 Act.

47 Article 4(1) 1/2010/Act.

48 Article 443(2) 1/2010 Act.

49 Article 448(1) $1 / 2010$ Act.

50 Gesetz zur Modernisierung des GmbH-Rechts und zur Bekämpfung von Missbräuchen (MoMiG), Bundesgesetzblatt 2008, Teil I Nr. 48, pp. 2026-2047. Retrieved 30 June 2017 www.bgbl.de; see C. Teichmann, 'Modernizing the GmbH: Germany's Move in Regulatory Competition', European Company Law 7(1) (2010) 20.

51 See H. Fleischer, 'A Guide to German Company Law for International Lawyers - Distinctive Features, Particularities, Idiosyncrasies', in: H. Fleischer, J. Lau Hansen, W.G. Ringe (eds) German and Nordic Perspectives on Company Law and Capital Markets Law (Beiträge zum ausländischen und internationalen Privatrecht, 109) (Tübingen: Mohr Siebeck, 2015) $3^{-25}$.

$52 \quad$ Para. $5 \mathrm{a}(1) \mathrm{GmbHG}$.

53 Para. 5 GmbHG.
} 
The incorporation of an UG is only possible under strict conditions, which clearly shows that the German legislator takes the minimum capital requirement still seriously. The first condition is that prior to the application for entry in the Commercial Register the issued capital of an UG has to be paid up in full in cash; contributions in kind are not allowed. ${ }^{54}$ Like a $\mathrm{GmbH}$ an UG will only come into existence upon its registration in the Commercial Register.

The second condition is that if after its formation the UG starts making profits, 25 percent of these profits have to be transferred to a legal or statutory reserve. This legal reserve will accumulate and may not be distributed. ${ }^{55}$ This legal reserve may be used only to cover an annual or accumulated deficit or may be used for recapitalizations. The reason for requiring this legal reserve is that an UG's lack of capital is not intended to be permanent, but is accepted only for a transitional period. The UG should continuously increase its capital until it eventually reaches the minimum capital limit of EUR 25,000 as prescribed for a regular GmbH. Once the issued capital of the UG has increased to EUR 25,000, the obligation to accumulate reserves ceases to exist. After an application for a change of the name (in order to add the supplement of GmbH instead of UG) and therefore the legal form with the Register Court ('Handelsgericht'), the UG will turn into a regular $\mathrm{GmbH} .{ }^{56}$ However, there is no period of time prescribed nor an obligation to transform the UG into an GmbH. It is imaginable that an UG decides to maintain its legal status as an UG although its issued capital has exceeded the minimum capital figure prescribed for a regular $\mathrm{GmbH}$.

\subsection{The Impact of the EU-Harmonisation Company Law Programme on National Legal Forms}

In order to attain freedom of establishment for companies within the $\mathrm{EU}$, Article $50(2)(\mathrm{g}) \mathrm{TFEU}$ provides for a duty of the EU bodies to act, through Directives which will co-ordinate to the necessary extent the safeguards which, for the protection of the interests of members and others, are required by Member States of companies or firms with a view to making such safeguards equivalent throughout the EU. So far eleven main company law Directives were enacted. ${ }^{57}$

54 Para. 5a(2) GmbHG.

55 Para. 5a(3) GmbHG.

56 Section. $5 \mathrm{a}(4) \mathrm{GmbHG}$.

57 The harmonised topics are the following: disclosure of the company's legal and financial situation, unrestricted power of representation, and restricted grounds for the nullity of companies (First Directive; now Directive 2009/101/EC); raising of capital, its protection, changes of capital and equal treatment of shareholders (Second Directive; now: Directive 2012/30/EU); judicial mergers and divisions (Third Directive; now: Directive 2011/35/EU, and Sixth Directive); cross-border mergers (Directive 2005/56/EC); accounting law 
A Directive is a very interesting instrument of European law. It is quite different from national legislation instruments. Although a Directive is binding on a Member State, it may choose the form and methods for the implementation of the provisions of the Directive into national legislation..$^{58}$ So, if a Directive is enacted on a certain subject, the result will not be uniform or identical law in the (still) $28 \mathrm{EU}$-Member States. The objective of harmonisation is that the law on a certain subject is deemed to be equivalent in the EU Member States.

Considering the usefulness of the SUP as a legal form for SMEs one should be aware of the fact that because of this EU harmonisation programme, companies seated in the EU already face similar national rules in respect of the harmonised topics. These topics differ from representation and capital protection to accounting and restructuring measures. However, the scope of the Directives is sometimes limited to a certain type of company. For instance, Directive $2012 / 30 / \mathrm{EU}$ in respect of capital and creditor protection is applicable to public companies only, and Directive 2004/25/EC in respect of takeover bids only to listed companies. Meanwhile, some very important topics have not been harmonised, such as the requirements for incorporating a company, and in respect of private companies, the rules for capital and creditor protection. Introducing the sup for single-member companies presents an opportunity to indirectly harmonise national law with respect to private companies (see section 3.11.).

\subsubsection{Rules for Single-Member Companies at the EU Level}

The single-member company is an interesting phenomenon, since company law was originally developed for companies with more than one member. The company is typically set up as an association of several members. For a long time the formation of a company by one person was forbidden in a number of Member States. These Member States justified the prohibition of single-member companies by arguing that a company is a contract between two or more shareholders and by their concerns that the single member acting in bad faith might abuse the company. An important development at the European level was that in December 1989 the Council of the European Communities adopted the

and auditing (Fourth, Seventh and Eight Directive; now: Directive 2013/34/EU); single member limited liability company (Twelfth Directive; now Directive 2009/102/EC); cross-border establishment of branches (Eleventh Directive); European Works Council (Directive on the establishment of a European works council); takeover bids (Directive 2004/25/EC) and the exercise of certain rights of shareholders of listed companies (Directive 2007/36/EC). The First, Second, Third, Sixth, Tenth and Eleventh Directive are recently consolidated in the New Directive 2017/1132/EU.

$5^{8}$ The definition of directive can be found in Article $288 \mathrm{TFEU}$. 
Twelfth Company Law Directive. ${ }^{59}$ The aim of this Directive was to introduce one man companies in all Member States. In view of this, the Directive states that a private company may have only one member, both at the time of its formation and also afterwards in case its shares are held by a single member.

The European legislator interfered with the one man company because it was thought desirable to supply the sole trader throughout the European Union with a legal instrument which allows him to limit liability. This way the sole trader is encouraged to take the risk of setting up a business in the form of a company. The limited liability company was regarded as a necessary condition for business development in the European internal market.

In fact, the single-member company was the first $\mathrm{EU}$ legal form for business entities. The Twelfth Company Law Directive introduced a legal instrument allowing for the limitation of liability of a private company with a single member throughout the EU. The only exception is that a Member State does not need to allow the formation of a single-member private company where its legislation provides that an individual entrepreneur may set up an undertaking with limited liability under the conditions laid down in Article 7 of said Directive.

The Twelfth Company Law Directive provides for a limited harmonisation of the relevant national laws, because it does not address many key issues such as formation, registration, creditors' protection and minimum capital requirements. It only provides for some specific rules. One of these rules is that the identity of the single member should be disclosed to the public by an entry in the commercial register. ${ }^{60}$ The underlying reason is that the fact that the company only has one member may be of interest to those dealing with it. Furthermore, it was provided that the single-member exercises all the powers of the general meeting and his decisions in this capacity must be recorded in minutes or drawn up in writing. ${ }^{61}$ The same applies to contracts between the sole member and his company as represented by him, with the exception of contracts concluded under market conditions in the ordinary course of business. ${ }^{62}$ Where a Member State allows the single-member public company as well, the aforementioned specific rules shall also apply. ${ }^{63}$

The principal rule of the Twelfth Company Law Directive is that a natural person who holds all the shares of one private company cannot be held liable for

59 Directive 89/667/EEC, which was codified by Directive 2009/102/EC of 16 September 2009 OJ L $258 / 20$.

6o Article 3 Directive 2009/102/EC.

61 Article 4 Directive 2009/102/EC.

62 Article 5 Directive 2009/102/EC.

63 Article 6 Directive 2009/102/EC. 
the company's debts merely because he is the sole member. The European legislator permits Member States - pending the co-ordination of national provisions on the laws relating to groups which has never materialised - to make special provisions and penalties for cases (i) where a natural person is the sole member of several companies; or (ii) where a single-member company or any other legal person is the sole member of a company. ${ }^{64}$ With this provision the European legislator took account of the differences that at that time existed in the national laws of the Member States, especially in respect of the law in groups of companies. For that purpose it is at the discretion of the Member States whether the privilege of limited liability applies where a legal person is the sole member of a company. ${ }^{65}$ As we will see in section 3.6., in this respect the European legislator has taken another course with the new legal form of the SUP.

2.3.2 Relationship between the Twelfth Company Law Directive (Directive 2009/102/EEC) and the Draft SUP Directive

As mentioned in section 2.3.1., Directive 2009/102/EEC is applicable to two types of single-member companies: (i) single-member private limited liability companies; and (ii) single-member public limited liability companies, if the law of the Member State allows public companies to be incorporated as or become single-member public companies.

The question arises as to what the exact relation is between Directive 2009/102/EEC and the draft SUP Directive. In order to answer this question, we will have to closely examine the draft sup Directive. It consists of three Parts (for a more extensive overview see section 3.1.). Part I contains provisions (Articles 3-5) which Member States must implement for all national forms of single-member limited liability companies. These provisions are similar to the provisions of Directive 2009/102/EC as discussed in section 2.3.1. The core of the draft sup Directive is formed by Part II (Articles 6-25) requiring the Member States to provide for a company form for single-member private limited liability companies in their national legislation. This new legal company form will be known under a common label in the Member States as Societas Unius Personae (sUP). Part III (Articles 26-33) contains final provisions, mostly regarding the relationship between the EU and the Member States.

It follows from the tenth consideration of the preamble of the draft SUP Directive that it does not aim to replace the existing national forms of singlemember companies. Member States' existing traditions of company law are respected. For that reason, flexibility will be afforded to them as regards the

64 Article 2(2) Directive 2009/102/EC and recital 5 of its preamble.

65 See e.g., the implementation of this provision in Belgian law. Especially Article 213 BCC. 
manner and extent to which they wish to apply harmonised rules governing the formation and operation of suPs. It is up to the Member States to choose between: (i) an exclusive system whereby not only Part I but also Part II of the draft suP Directive applies to all single-member private limited liability companies so that all these companies are to operate and be known as SUPs; and (ii) an alternative/parallel system which provides for the establishment of an SUP as a separate legal company form existing in parallel with other forms of single-member private limited liability companies provided for in national law. In that case, a Member State knows at least two forms of single-member limited liability companies: the SUP to which Part I and Part II of the draft suP Directive apply, and other types of single-member limited liability companies (private and/or public) to which only Part I of the draft sup Directive is applicable.

Member States are obliged to adopt, publish and apply not later than 24 months after the date of entry into force of the sup Directive, the laws, regulations and administrative provisions necessary to comply with the SUP Directive (Article 31). Directive 2009/102/EC will be repealed 24 months after the date of entry into force of the SUP Directive. References to the repealed Directive shall be construed as references to the sup Directive and shall be read in accordance with the correlation table in Annex II (Article 29).

\subsection{Supra-National, European Legal Forms: European Character?}

So far there are three EU legal forms for supra-national business entities: the European Economic Interest Grouping (E EIG ), 1985; ${ }^{66}$ the European Company (SE ), 2001; ${ }^{67}$ and the European Co-operative Society (SCE ), 2003. ${ }^{68}$ By establishing these legal forms the EU has provided businesses with instruments under EU law for cross border co-operation. In June 2008, the Commission proposed another new EU legal form, that of a European Private Company (Societas Privata Europaea (SPE)). ${ }^{69}$ Due to criticisms from the Member States, in 2013 it was decided to withdraw the proposal for an SPE regulation. ${ }^{70}$

66 Council Regulation (EEC) No 2137/85 of 25 July 1985 on the European Economic Interest Grouping (EEIG) [1985] OJ L 199/1.

67 Council Regulation (EC) No 2157/2001 of 8 October 2001 on the Statute for a European company (SE) [2001] OJ L 294/1.

68 Council Regulation (EC) No 1435/2003 of 22 July 2003 on the Statute for a European Cooperative Society (SCE) [2003] OJ L 207/1.

69 'Proposal for a Council Regulation on the Statute for a European private company' $\operatorname{com}(2008) 396 / 3$ (2008 June).

70 This was decided during the 2013 Regulatory Fitness and Performance (REFIT) programme: 'Results and next steps' (сом(2013)685pdf. The formal withdrawal was published in the Official Journal of the EU on 21 May 2014. 
Of the three established EU corporate forms, only the Societas Europaea (SE) is a capital company and it is also the best known and most used form. To support this: on 12 May 2017, 2774 SE's were established. ${ }^{71}$ The SE, a European public company, is - just like the other Eu legal forms - based on a European Regulation. A Regulation has general application and is binding in its entirety. A provision in an EU Regulation is directly applicable in the Member States; ${ }^{72}$ as opposed to a provision of an EU Directive, it does not need to be implemented in national law. So this is genuine Eu legislation. However, the legal form of the SE is not entirely regulated by EU law. In the SE Regulation some options are included for the Member States, so there is some implementation law. Besides that, some topics are not regulated in the SE Regulation. The result is that the $\mathrm{SE}$ is not only governed by $\mathrm{EU}$ law but also by national law. In reality there are 28 different company law regimes for the SE, depending on the law of the seat of incorporation of the relevant SE. So, the place of incorporation of the SE, or in other words, the place where the SE has its registered office, is decisive for its applicable law.

There are some restrictions for incorporating an SE. The ultimate goal of the $\mathrm{SE}$ is to facilitate and promote the crossing of borders by enterprises within the EU. ${ }^{73}$ That is the reason why at the time of incorporation of an SE a crossborder requirement must be fulfilled, meaning that the companies forming an SE are governed by the law of different Member States or have had a subsidiary or a branch in another Member State for at least two years before the creation of the SE.

Furthermore, the SE is meant for relatively large companies. Consequently, under some circumstances - the formation of an SE by cross-border merger or by way of a conversion - only public companies can promote the incorporation of an SE. ${ }^{74}$ The fact that the $\mathrm{SE}$ is meant for relatively large companies also explains the minimum capital requirement of EUR 120,000. ${ }^{75}$

As described in section 2.2.1., at present there are two different systems for the board structure of public companies in the European Union. In some Member States the two-tier board structure is mandatory, whereas in some other Member States only the one-tier board structure is available to public companies. However, in a significant number of Member States a public

\footnotetext{
71 Consult www.ecdb.worker-participation.eu/news.php.

72 The definition of regulation can be found in Article $288 \mathrm{TFEU}$.

73 Recitals 10 and 11 of the preamble of the SE Regulation.

74 See for the cross-border merger Articles 2(1) and 17 SE Regulation and for the conversion Articles 2(4) and 37 SE Regulation.

75 Article 4(2) SE Regulation.
} 
company may choose between a one-tier and a two-tier board structure. The SE Regulation also leaves it to the founders of the SE to choose between the two systems. ${ }^{76}$ This means that in some countries founders of an SE have this choice while founders of a national company do not, e.g. in Germany for an Aktiengesellschaft the two-tier board structure is obligatory.

It is noteworthy that the creation of the SE was subject to negotiations for more than 30 years. The main reason it took so long was that Member States had, and still have, very different views with regard to employee involvement. With this it is meant that any mechanism through which employees may exercise an influence on decisions to be taken in a company, such as the right of employees or employees' representatives to be informed and consulted about certain matters. A particular problem was posed by the so-called employee participation rights. Employee participation refers to the influence that employees, or employees' representatives, have on the composition of the supervisory (two-tier board) or the administrative board (one-tier board) of a company. This influence would consist of the right to elect or appoint some of the members of the company's supervisory or administrative board or the right to recommend and/or oppose the appointment of some or all of the candidates for membership of the company's supervisory or administrative board. In the process of the creation of the SE some Member States, for instance Spain, Portugal and the United Kingdom, were reluctant to introduce companies with employee participation rights into their domestic legal system. ${ }^{77}$ Other Member States, for instance Germany and the Netherlands, feared that companies would choose the SE in order to escape from the national provisions laid down with respect to employee participation. German law provides for extensive involvement of employees in national companies through employee participation rights in the various Co-Determination Acts. In the Netherlands, the socalled structure regime is an example of employee participation rights.

A solution was found in the form of a specific Directive: the SE Directive. ${ }^{78}$ However, this Directive is based on a complicated compromise. The central theme of the SE Directive is that the involvement of employees in a forthcoming SE is the subject of negotiations. A special negotiating body of employees' representatives and the management of the companies establishing an

76 Article 38 (b) sE Regulation.

77 See, about the disagreement at a political level centering on employee participation provisions: V. Edwards, 'The European Company - Essential Tool or Eviscerated Dream?', Common Market Law Review $40(2)$ (2003) 448.

${ }_{78}$ Council Directive 2001/86/EC of 8 October 2001 supplementing the Statute for a European company with regard to the involvement of employees [2001] OJ L 294/22. 
SE need to negotiate on the form and extent of employee involvement. If no agreement is reached within six months (with the possibility to renewal for one year), default rules as set out in the Annex to the SE Directive will apply the so-called reference provisions. The applicable regime involves a regime of information and consultation of employees or employees' representatives and a regime of employee participation. ${ }^{79}$ However, the reference provisions will not apply if the special negotiating body of employees' representatives decides not to open negotiations or to terminate the on-going ones and to simply rely on the rules for employee involvement in force in the Member States where the SE has its employees. ${ }^{80}$

\section{Analysis of the Proposed Legal Form of the SUP ${ }^{81}$}

In order to answer the question whether the SUP is an effective legal form for individual entrepreneurs as well as for subsidiaries within a group, the main characteristics will be pointed out (see sections 3.4.-3.9.), but first we will make some preliminary remarks in respect of the draft suP Directive (sections 3.1.-3.3.).

79 See J.N. Schutte-Veenstra and E.E.G. Gepken-Jager, 'sE and cross-border worker participation; the Dutch implementation', in: Recasting Worker Involvement (Deventer: Kluwer, 2009) 188-189.

8o Article $3(6)$ SE Directive.

81 See for some literature on the SUP: European Company and Financial Law Review 2015, Volume 12 number 2 in which the following articles are published: P.H. Conac, 'The Societas Unius Personae (sup): A “Passport” for Job Creation and Growth', European Company and Financial Law Review 12(2) (2015) 139-176; J. Lau Hansen, 'The sup Proposal: Registration and Capital (Articles 13-17)', European Company and Financial Law Review 12(2) (2015) 177-19o; V. Knapp, 'Directive on Single-Member Private Limited Liability Companies: Distributions', European Company and Financial Law Review 12(2) (2015) 191-201; C. Teichmann, 'Corporate Groups within the Legal Framework of the European Union: The Group-Related Aspects of the sup Proposal and the EU Freedom of Establishment', European Company and Financial Law Review 12(2) (2015) 202-229; C. Malberti, 'The relationship between the Societas Unius Personae proposal and the acquis: Creeping Toward an Abrogation of EU Company Law?', European Company and Financial Law Review 12(2) (2015) 238-279. See also: P. Hommelhoff, 'Die Societas Unius Personae: als Konzernbaustein momentan noch unbrauchbar' ('The suP: not yet useful as a building block for groups of companies'), GmbHRundschau 20 (2014) 1065-1075; I. Wuisman, 'The Societas Unius Personae (SUP)', European Company Law 12(1) (2015) 34-44; and P. Kindler, The Single-Member Limited Liability Company (sUP) (München: C.H. Beck, 2016). 


\subsection{Scope and Content of the Draft suP Directive}

As described in section 2.3.2. the draft sup Directive is not only applicable to the sup, but also to single-member private and public companies. The draft sup Directive consists of three Parts.

Part I of the draft suP Directive contains provisions (Articles $3-5$ ) which Member States must implement for all types of single-member limited liability companies. These provisions are similar to the provisions of Directive 2009/102/EC (see section 2.3.1.). The identity of the single-member should be disclosed to the public by entry into the commercial register. Furthermore, decisions taken by the single-member exercising the power of the general meeting should be recorded in writing. The same applies to contracts between the single-member and the company, with the exception of contracts concluded under normal market conditions.

The essence of the draft sup Directive is formed by Part II (Articles 6-25) requiring the Member States to introduce into their national legislation a new legal company form for single-member private limited liability companies known under the common label of an SUP. Furthermore, the draft suP Directive determines, to a certain extent, the legal framework of the SUP. Nevertheless, the Member States' 'own' national rules will also be of importance, such as the rules of liability of directors and members.

Part III (Articles 26-33) contains final provisions, especially regarding the relationship between the EU and the Member States. These provisions refer among others to the conferment of power on the Commission to adopt delegated acts and to the obligation of Member States to provide for appropriate penalties applicable to infringements of the national provisions adopted to implement the SUP Directive.

\subsection{Choice between an Exclusive and a Parallel System}

As described in section 2.3.2., Member States have the choice between an $e x$ clusive system and an alternative/parallel system. It is likely that most of the Member States will opt for a parallel system for the following reasons.

First of all, this system will be chosen because of the limited usefulness of the SUP. The SUP is designated for only one member. Over time it may appear that the concept of one member no longer suffices. Examples of this are the situation that the sole member deceases and his heirs wish to continue the enterprise of the SUP and the situation where the SUP needs additional funding and new shares must be issued to third parties. In these cases, the legal form of the SUP no longer suffices. It is true that the SUP may be converted in a 'common' multi-member private company, but this will take time and money. 
Second, in a parallel system, already existing single-member private limited liability companies will not be forced to convert themselves into an SUP.

\subsection{Compromise Text: Uniform Framework for the sUP Replaced by National Variety}

It is notable that where the proposal for the sup Directive on a number of important issues provides for uniform arrangements for the SUP, the compromise text mainly leaves the content of the national legislation applicable to the SUP to the Member States. We give some examples:

(i) The time at which an SUP acquires legal personality is no longer linked to its (online) registration. It is left to each Member State to determine the connecting factor for the acquisition of legal personality.

(ii) The standard template of articles of association to be adopted by the Commission is replaced by a national template to be adopted by each Member State.

(iii) The provision that both seats - the seat of incorporation and the real seat - do not necessarily need to be in the same Member State has been replaced by the provision that a Member State may apply the doctrine of the real seat to its own national sups.

(iv) A uniform regime on the distribution of dividends has been replaced by the rule that each Member State adopts a system of creditor protection that will prevent the suP from being unable to pay its debts after a distribution of dividends.

(v) The right of the single member to give instructions to the management body is eliminated.

\subsection{Formation SUP Ex Nihilo or by Conversion}

The draft sup Directive restricts the possible ways of forming an Sup to either incorporating a company ex nihilo (founding an entirely new company) or converting an already existing private company into an SUP.

3.4.1 Incorporation and Registration

The incorporation of an SUP is not restricted to natural persons. A legal person (including another SUP) is entitled to incorporate an SUP as well. The draft SUP Directive does not require that the founder of the SUP is a resident of the EU or has a seat in the EU. ${ }^{82}$ If allowed by the national law of the Member State of

$82 \quad$ But contrast Wuisman (n 81) 36 . 
registration, an SUP may also be incorporated by other entities not having legal personality (Article 8).

The draft sup Directive requires Member States to offer a registration procedure that can be fully completed electronically without requiring a physical presence of the founder before the authorities of the Member State of registration. ${ }^{83}$ In line with the recommendations set out in the European Commission's 2011 Review of the Small Business Act ${ }^{84}$ to reduce the start-up time for new enterprises, Article 14(3) draft suP Directive prescribes that an SUP should receive the certificate of registration in the relevant register of a Member State within five working days from the receipt of all the necessary documentation and information by the competent authority. This facility must be offered only to newly created sUPs. The conversion of existing entities into SUPs may, by their very nature, take more time. ${ }^{85}$

An sup is registered in the Member State in which it is to have its registered office (Member State of registration). An suP acquires legal personality on the date determined by the national law of the Member State of registration (Article 14(2)). This is in line with the general provision in Article 7(4) that an SUP, and its articles of association, is governed by the national law of the Member State of registration. In addition to the online registration Member States may allow SU Ps to be registered in other ways (Article 14(3)).

In the draft sup Directive it is made clear that Member States are allowed to maintain existing rules or enact new rules concerning possible verification of the legality of the registration process, including rules on the verification of identification and legal capacity of the founder. Such rules may include, for example, the legality check via a video-conference or other online means that provide a real-time audio-visual connection. However, in any event national rules may not affect the possibility of completing the whole registration procedure online. ${ }^{86}$ Article 14b of the draft suP Directive contains provisions on the online cross-border identification of the founder of an SuP. The Member State of registration has to recognise electronic identification means issued in another Member State and notified to the European Commission, in accordance with the eIDAS Regulation. ${ }^{87}$ EIDAS stands for electronic identification and

83 Explanatory Memorandum to the proposal for an Sup Directive, (n 1 ) 7 .

84 'Communication from the Commission to the European Parliament, the Council, Economic and Social Committee and the Committee of Regions' $\operatorname{COM}(2011) 78$ final (February 2011).

85 Recital 16a of the preamble.

86 Recital 18 of the preamble.

87 Regulation (EU) No 910/2014 of the European Parliament and of the Council of 23 July 2014 on electronic identification and trust services for electronic transactions in the internal market and repealing Directive 1999/93/EC [2014] OJ L 257/73. 
signature. The eIDAS Regulation has introduced mutual recognition of eID's and electronic trust services, including e-signatures, electronic seals and electronic time stamps, within the EU-Member States. In respect of e-signatures the eIDAS Regulation ensures that e-signatures have the same legal effect as traditional 'wet ink' signatures. Also, electronic seals and electronic time stamps shall not be denied legal effect and admissibility as evidence in legal proceedings solely on the grounds that they are in an electronic form. In addition to the rules as set out in the eIDAs Regulation, the Member State of registration may recognise other electronic and non-electronic means of identification. If, for the purpose of registration, the registration authorities recognise non-electronic identification means issued in the Member State of registration, they must also recognise the same type of identification means issued in other Member States. ${ }^{88}$

With this whole set of guarantees related to the online registration of an suP in order to make it as secure and compliant with existing national rules as possible, it is believed that the risks of any misuse have been minimised. One should also bear in mind that these guarantees are without prejudice to any anti-money laundering rules. ${ }^{89}$

\subsubsection{Information to be Made Available to the Founder of an SUP}

Each Member State has to make available to the founder of an SUP, before registration, up-to-date, clear, concise and user-friendly information about national law governing at least the aspects (of functioning and registration of an suP) listed in Article 12(1) of the draft sup Directive. This includes, inter alia, the powers and responsibilities of the management body, powers of the single member, the regulation of (dividend) distributions and formalities related to the registration of an SUP.

Member States are also obliged to make available the relevant provisions of default national laws governing at least the above-mentioned aspects of the functioning and registration of suPs, if any, or references to those provisions.

Article 12(3) of the draft sup Directive further prescribes that each Member State has to include on his national online registration website for suPs links to the online registration web-sites for sups in other Member States. This obligation may be fulfilled by a Member State via a link to a central EU-web-site, such as the European e-Justice portal, providing the links to all online SUP registration points in the Member States.

88 Recital 18a of the preamble.

89 See the Note from the General Secretariat of the Council to the Council of 21 May 2015, $8811 / 15$, DRS 39, CODEC 706, 3/4. 


\subsubsection{Conversion}

An suP may also be formed by the conversion of an existing private company as listed in Annex I (Article 9(1)). The formation of an sup by conversion shall not result in any winding-up procedures, any loss or interruption of the legal personality or affect any rights or obligations existing prior to the conversion (Article 9(2)). The sup simply assumes the rights and duties of the private company existing prior to the conversion. It is up to national law to provide for a conversion procedure. According to recital $11 \mathrm{~b}$ of the preamble, a crossborder conversion of, for example, a Dutch BV into a German SUP, is only possible if this is allowed by the national laws of both Member States. The reasons mentioned are that the subject of cross-border transfer of registered offices is not harmonised at the EU level and that it is without prejudice to the case-law of the European Court of Justice (ECJ). However, in respect of the latter, according to the judgments of the ECJ in the Cartesio ${ }^{90}$ and the Vale cases, ${ }^{91}$ one could argue that, on the one hand, a home state may not hinder a company from converting itself into a company governed by the law of the host state and, on the other hand, that whenever a host state provides for an internal conversion procedure, a company incorporated in another state may rely on this provision. The same applies to the cross-border conversion of a private company into an SUP.

The draft sup Directive does not allow the direct conversion of a public company into an SUP. The reason why this facility is not offered is not clear. It is also not justified, because an indirect route is available, i.e. a public company is able to convert itself into an sup after a conversion into a private company.

\subsubsection{Establishment of an SUP}

The registered office of an SUP must be situated in an E U Member State (Article 14 (1)). The draft SUP Directive does not prescribe that both seats - the seat of incorporation and the real seat - of the SUP need to be in the same Member State. In this respect, the European Commission differs from the provision in the SE Regulation, that the registered office of an SE shall be located in the same Member State as its head office. ${ }^{92}$ It is an important and welcome development that the Commission no longer supports the application of the real seat theory to a European legal form. This is in line with the case-law of the ECJ in respect of national companies, especially the already mentioned Cartesio judgment, in which the ECJ made it clear that a Member State may only apply

\footnotetext{
90 ECJ Case C-210/06 Cartesio [2008] ECR I-09641.

91 ECJ Case C-378/10 VALE Épitési [2012] ECLI:EU:C:2012:440.

$92 \quad$ Article 7 SE Regulation.
} 
the real seat theory to its own companies, and not to companies incorporated in another state. Accordingly, a Member State may still apply this theory to its own national SUPs. For an SUP registered in a Member State that adheres to the real seat theory, it may not be possible to separate its registered office and its central administration or principal place of business. This may result in a liquidation or winding-up procedure or a loss of its legal personality according to the law of the Member State of incorporation, or conversion.

In Member States which adhere to the incorporation theory a parent company is facilitated in order to incorporate and register all its subsidiaries in the form of an SUP in the same Member State and to separately set up the offices for the central administration of these subsidiary sups in the Member State where each conducts its main activities. In that way, the parent company only needs to familiarise itself with the company law regime of one Member State, preferably its own. However, it could be a disadvantage for the business partners of these subsidiary suPs: they must make themselves familiar with the provisions of a foreign company law regime.

\subsection{Template for the Instrument(s) of Constitution}

Member States must make available an online template for each instrument of incorporation of an SUP (Article 11(1)). Article 11(3) prescribes some requirements in respect of the information to be provided by a founder of an SUP in the national template(s). Where a founder of an suP uses the national template(s), the relevant Member State ensures that the SuP can be registered online.

Reference is made to one or more instruments of constitution, because according to some national company laws there is only one instrument of constitution including the articles of association - e.g. Dutch law: Article 2:177 (1) DCC prescribes that the notarial deed of incorporation must contain the articles of association - and according to others the articles of association are contained in a document separate from the instrument of constitution - e.g. UK law: Sections 8, 18 and 21 CA 2006 provide for a memorandum of association that cannot be amended or updated and articles of association that can.

Where the instrument(s) of constitution is (are) drawn up and submitted online with the use of the national template(s) and have been accepted by the registration authority, this means that at the time of formation of an SUP these instruments are drawn up and certified in due legal form according to the relevant obligation under Article 11 Directive 2009/101/EC.

It is remarkable that the draft SUP Directive does not contain any provisions on the amendment of the articles of association of the SUP. 


\subsection{Privilege of Limited Liability for Both Natural and Legal Persons}

The draft sup Directive purports not only to facilitate individual entrepreneurs, but also benefits groups of companies by allowing them to set up singlemember subsidiaries according to the same main requirements across the $\mathrm{EU}$. Thus, it is explicitly stated in Article 8 that a legal person (including another SUP) is entitled to incorporate an SUP. Moreover, a natural person as well as a legal person may incorporate several suPs. This is a significant difference with the Twelfth Company Law Directive, which leaves it to the discretion of Member States whether the privilege of limited liability applies in these situations. With regard to the SUP, Member States are not allowed to make special provisions and/or penalties for cases (i) where a natural person is the sole member of several su Ps; or (ii) where a single-member company or any other legal person is the sole member of an SUP. This can be an incentive for a Member State to abandon such penalties, also for the regular national legal form of the singlemember private company, because there is no valid reason to treat both legal forms of single-member private companies in a different way. It is remarkable that in the announcements regarding the SUP the European Commission does not pay any attention to this implication of the draft suP Directive.

\subsection{Capital and Creditor Protection}

The SUP is designated for one member. For that reason, the SUP is only allowed to issue one single share that cannot be split (Article 15). Where a single share of an SUP is owned by more than one person - in particular in inheritance and matrimonial law - those persons shall be regarded as one member in relation to the sup.

The incorporation of an SUP is facilitated by a minimum capital requirement of EUR $1 .{ }^{93}$ The value of a minimum capital requirement is up for debate. ${ }^{94}$ One way of protecting creditors of a capital company is through

93 In Member States in which the euro is not the national currency, the share capital shall be at least equivalent to one unit of that Member States' currency (Article 16 (1)).

94 See e.g. about the different ways to protect company's creditors the contributions of various authors in: H. Eidenmüller and W. Schön (eds), The Law and Economics of Creditor Protection, A transatlantic Perspective (The Hague: TMC Asser Press, 2008); C. Jungmann, 'Solvenztest- versus Kapitalschutzregeln, Zwei Systeme im Spannungsfeld von Gläubigerschutz und Finanzierungsfreiheit der Kapitalgesellschaft', ZGR 5 (2006) 638-682; J. Rickford, 'Reforming capital: report of the interdisciplinary group on capital maintenance', European Business Law Review 15(4) (2004) 919-1026 at 930; and Report of the High Level Group of Company Law Experts on a Modern Regulatory Framework for Company Law in Europe, Brussels. November 2002. 68-69. Retrieved 3 July 2017 www.ecgi.org/publications/documents/report_en.pdf; H.E. Boschma, M.L. Lennarts and J.N. Schutte-Veenstra, 
provisions governing legal capital, as in the Second Company Law Directive. Legal capital provisions contain an asset protection system with a minimum capital requirement and a balance sheet net asset test for distributions. Another way of protecting creditors is through a system based on a combination of solvency protection and liability of directors (and possibly shareholders) for unlawful distributions and/or wrongful trading. In this latter system, a minimum capital requirement is superfluous. In the draft sup Directive the golden mean is chosen: a minimum capital is required, albeit a very low amount.

A low minimum capital requirement is in line with the approach already taken for private companies in a significant number of Member States. It could have the effect that start-up activities are stimulated as was the case in some Member States, e.g. France, Germany and Poland, where there was a significant increase in the number of new companies after the law reforms which lowered the minimum capital requirement. ${ }^{95} \mathrm{~A}$ possible reason for this is that a low minimum capital requirement allows the founder(s) flexibility in financing the activities of the company: by way of share capital or by borrowing money from a bank or otherwise. Having said this, we fail to see a good reason for not allowing Member States to waive the minimum capital requirement for an SUP. A minimum capital of EUR 1 only has symbolic value: it does not offer any more protection to creditors than no minimum capital whatsoever as is prescribed in the Netherlands.

While the minimum capital requirement of the SUP is fixed on EUR 1, the question arises how the protection of creditors is regulated, especially protection from excessive distributions to the single member. In this respect Article 18(1) draft SUP Directive requires that the Member States ensure the establishment of mechanisms in national law that would prevent suPs from being unable to pay their debts after making distributions. The choice of form and methods ensuring the compliance with this requirement is left to the Member States. In this context, Member States should be able, for example, to require sups to build a legal reserve, establish a minimum balance sheet test and/or require a solvency test with or without a solvency statement prepared and signed by the management body. ${ }^{96}$ The legal reserve as noted is the one provided for in Article 16(4): Member States may require the sup to build up a legal reserve as a percentage of the profits made by the sup and/or up to the amount of

'The Reform of Dutch Private Company Law: New Rules for the Protection of Creditors', European Business Organization Law Review 8(4) (2007) 567-604.

95 Memo European Commission, 9 April 2014, 'Proposal for a Directive on single-member private limited liability companies - frequently asked questions', 5 .

96 European Council, 29 May 2015, 9050/15 DRS 41 CODEC 751, 13. 
the minimum capital required for a private company. This provision bears a strong resemblance to the one prescribed for the German UG as described in section 2.2.3.

We welcome the fact that the Commission no longer supports the application of capital maintenance rules as laid down in the Second Company Law Directive for public companies. ${ }^{97}$ The Commission's proposal for a European Private Company (SPE $)^{98}$ was still largely based on these rules. ${ }^{99}$ It contained an asset protection system with a minimum capital requirement and a balance sheet net assets test for distributions. In our opinion, legal capital provisions are not adequate for the protection of company creditors. ${ }^{100}$ The reasons for this are not only that the provisions regarding the raising of capital go further than is necessary for their purpose of giving protection to creditors and involve unnecessary costs for businesses, but more importantly that the required balance sheet test for distributions does not provide creditors with the desired reasonable prospect that after making a distribution a company will be able to pay its debts as they fall due. That should be the basic principle for creditor protection, namely that creditors have a reasonable prospect that the company will meet its obligations to them in a timely fashion. ${ }^{101} \mathrm{~A}$ better way to protect company's creditors against dilution of the company's assets is a system based on a combination of solvency protection and liability of directors and members for unlawful distributions and/ or wrongful trading.

In respect of the sup Member States are given the freedom to choose the form of creditor protection and by doing so make a connection with the provisions for the regular private company. This is considered as progress in comparison with the proposed SPE Regulation.

97 Council Directive (2012/30/EU) of 25 October 2012 as regards the formation of public limited companies and the maintenance and alteration of their capital [2012] OJ L 315/74.

98 'Proposal for a Council Regulation on the Statute for a European private company' сом (2008) 396/3 of 25 June 2008. This proposal has been withdrawn.

99 See J.N. Schutte-Veenstra and M. Verbrugh, "The European Private Company and Capital Protection', European Company and Financial Law Review - Special Volume 3: The European Private Company - Societas Privata Europaea (SPE), in: H. Hirte and C. Teichmann (eds) (Berlin: Verlag Walter de Gruyter GmbH, 2012) 263-292.

100 See J.N. Schutte-Veenstra, H.E. Boschma, M.L. Lennarts, Alternative systems for capital protection (IVo-edition nr. 50, Deventer: Kluwer, 2005) 78; Schutte-Veenstra, Boschma, Lennarts, 'The Reform of Dutch Private Company Law' (n 94) 567-604.

101 See Rickford, 'Reforming capital' (n 94) 4. 


\subsection{The SUP and Employees' Rights}

The draft suP Directive does not introduce any new rules as regards employee involvement, i.e. rights of information and consultation of employees or employees' representatives and employee participation in the supervisory or administrative board of the sUP. Instead, the rights of the suP's employees will remain covered by existing national laws in respect of private companies. ${ }^{102}$

\subsection{Organisation of SUPS}

Each sup has a single-member and a management board composed of one or more directors. A supervisory board is optional (Article 22(1)). The draft SUP Directive is silent on the question of whether an SUP may provide in the articles of association for a one-tier board structure with executive and nonexecutive directors. We see no reasons why the two-tier board structure should be exclusively available to an SUP.

According to the general provision in Article 4(1) the single member exercises the powers of the general meeting of the SUP. The division of powers between the general meeting and the management board of an SUP is left to national legislation, notwithstanding the original proposal which contained a list of decisions which needed to be taken by the single member.

The draft sup Directive is also silent on the question of whether a legal person is allowed to be a director of an SUP. However, in order to increase the trustworthiness and reliability of sUPs, the draft suP Directive lays down provisions relating to the disqualification of directors (Article 22(3) and (4)).

\subsection{The Pros and Cons of the SUP}

The objective of this publication is to examine whether the SUP is an appropriate legal form for SMEs as well as for subsidiaries within the European Union. In other words: what are the pros and cons of the SUP? In order to answer this question, we distinguish between the SUP as a legal form for individual entrepreneurs and the SUP as a legal form for subsidiaries within a group.

102 Memo of the European Commission, 9 April 2014, 'Proposal for a Directive on singlemember private limited liability companies - frequently asked questions', 3 : '[a]s the suP would be a national and not a European legal form, it would not need to provide for a self-standing independent legal framework and therefore, more issues (e.g., involvement of employees, transfer of seat) could be regulated by national law'. See also consideration 10a of the compromise text of the draft sup Directive: '[t]o ensure consistency, in case of matters not regulated by this Directive, the rules applicable to private limited liability companies limited by shares in the Member State of registration of the suP should apply to SuPs ..... 


\subsubsection{Individual Entrepreneurs}

Since the adoption of the Twelfth Company Law Directive in 1989 and its subsequent implementation, individual entrepreneurs throughout the European Union are allowed to limit their personal liability for company's debts by using a single-member private company. In that respect, the suP brings nothing new. The surplus value of the sup for individual entrepreneurs lies particularly in the fact that all Member States should allow the incorporation of an SUP online in its entirety, without the need for the founder to appear physically before any authority in the Member State of registration. In other words, notarial intervention may not be required for the incorporation of an SUP, at least not in a way that interferes with the online incorporation procedure. An online template for the instrument(s) of incorporation as well as an online registration template will be available. Furthermore, the incorporation of an SUP is facilitated by a minimum capital requirement of EUR 1. This could be attractive for individual entrepreneurs who are established in Member States that do not have the possibility of an online-incorporation and/or require a substantial minimum capital for the incorporation of a private company.

However, the SUP also has a downside because of its limited usefulness. The sup is designated for only one member. During its life span it may turn out that the concept of one member no longer suffices. Examples of this are the situation that the sole member is deceased and his heirs wish to continue the enterprise of the SUP and the situation that the SUP needs additional funding and new shares should be issued to third parties. Under these circumstances the sUP must be converted in a 'common' multi-member private company. However, this is time- and money-consuming.

\subsubsection{Subsidiaries}

The draft SuP Directive enables groups of companies to set up subsidiaries across the $\mathrm{E} U$ in the legal form of an SU P. Member States are not allowed to make special provisions and/or penalties for cases where a single-member company or any other legal person is the sole member of an sUP. Furthermore, the draft sup Directive offers Member States that adhere to the incorporation theory the possibility of allowing the separation of the registered office and the head office of sUPs. This enables a parent company to incorporate and register all its subsidiaries in the form of an SUP in the same Member State and to set up separately the offices for the central administration of these subsidiary suPs in the Member State where each conducts its main activities. In that way, the parent company only needs to familiarise itself with the company law regime of one Member State, preferably its own. However, it could be a 
disadvantage for the business partners of the sups: they must make themselves familiar with the provisions of a foreign company's legal regime.

Nonetheless, it remains to be seen whether parent companies will make use of the possibility to incorporate all their subsidiaries in the form of an SUP in the same Member State. We refer to experiences gained in Germany. When eliminating the real seat doctrine ${ }^{103}$ the German legislator hoped that German parent companies would incorporate all their 'foreign' subsidiaries as German companies. This did not prove to be true, for the reason 'that this kind of group structure would jeopardise the acceptance of the subsidiaries in their host countries.'104

Also, it is doubted in German academic literature whether the SUP will be suitable as a building block for groups of companies. The reasons for this doubt are that the draft sup Directive contains no uniform standards for (i) the right of the single member to give instructions to the management board; ${ }^{105}$ and (ii) directors' liability. ${ }^{106}$

\subsection{Do We Need the suP?}

The question may arise whether or not we need the SUP? In our view, it is not necessary to introduce the new legal form of the SUP in order to achieve the goals set by the European legislator. These goals could also be achieved by forcing the Member States to offer to a natural person and a legal person the possibility of incorporating a regular single-member private company with a minimum capital of only EUR 1 (or even without a minimum capital) online. At

103 In 2008 for the $\mathrm{GmbH}$ and in 2010 for the AG.

104 Kindler, The Single-Member Limited Liability Company (suP) (n 81) 36.

105 We note that the Forum Europaeum on Company Groups (FECG), composed of academics and practitioners from various European States with professional affinity to the law on groups, proposed a simplified system for Service Companies (see Forum Europaeum on Company Groups, 'Proposal to Facilitate the Management of Cross-Border Company Groups in Europe', European Company and Financial Law Review 12(2) (2015) 299-306). The principal rule in this simplified system is that a Service Company must observe all directions from the parent company. There are, however, exceptions to this rule. There is no need to follow directions of the parent company if these have the effect that the Service Company is not able to fulfil obligations falling due within twelve months following the direction or that the existence of the Service Company is endangered. The FECG suggested that the simplified system proposed for Service Companies could be tackled immediately by the European Legislator in the context of preparing the sup Directive. However, in the compromise text of the sup Directive the right of the single member to give instructions to the management body was eliminated (see section 3.3.).

106 Kindler, The Single-Member Limited Liability Company (sUP) (n 81) 31-38; Hommelhoff, 'Die Societas Unius Personae' (n 81) 1065-1069. 
the same time, we do realise that such a harmonisation of the national law regarding the regular private company may not be feasible (yet). It is not unlikely that a large number of Member States may well want to adhere to their own established rules of private company law as far as possible, but are willing to adapt their national legislation for the static legal form of the SUP. Here again the paradox in European Company Law earlier outlined by Jaap Winter ${ }^{107}$ appears. The choice falls on the SUP, because Member States are prepared to renounce their 'own' private company law for the static legal form of the suP. Later on, it will be shown that there is no (great) need for the SUP because of its limited usefulness. Meanwhile the facilitative arrangements applicable to the sUP - like the online incorporation and registration and the online templates could have the side effect of pressuring Member States into also offering these facilities to other national legal forms; at least to national private companies and possibly also to national public companies. In the long term this will lead to an adjustment of national company law which was appropriate from the beginning. Thus, the indirect impact of the sup could be large. What seems like a fairly harmless harmonisation, because only some specific rules in respect of a special type of a single-member private company called suP should be introduced while leaving the national rules in respect of single-member companies untouched, could eventually lead to a more or less harmonised law of private and possibly even public companies.

\section{Disintegrating National Influences of the Introduction of the SUP}

There might be some disintegrating influences between Member States which could hinder the introduction by the European legislator of a new legal enterprise form like the SUP. In this respect, we will discuss the following subjects: the system of incorporation, creditor protection, board structure and employee participation.

107 Jaap Winter outlined this paradox in EU company law with regard to the SE. An example: the founders of an SE were given the option to choose between a one-tier and a two-tier board structure. Later on, this option became available to regular public companies in a lot of Member States. See J. Winter, 'De paradox van de Europese vennootschap' ('The paradox of the European Company'), in: Europees ondernemingsrecht: 5o jaar na Sanders' Europese NV (European company law: 50 years after Sanders' European Public Company) (Deventer: Kluwer, 2010) 100, 105-106. 


\subsection{Incorporation of a Company: Notarial Intervention vs Online Incorporation}

In the European Union two different systems for the incorporation of companies can be distinguished. In a significant number of Member States (e.g. the United Kingdom, Ireland, Denmark, Sweden, Finland) the incorporation of public and private companies can be completed fully electronically, without requiring the intervention of a public notary. In other Member States (e.g. Germany, Italy, the Netherlands, Austria, Luxembourg) the incorporation of a capital company requires a deed executed by a public notary (or an attorney).

The starting point of the draft suP Directive is that each Member State has to provide for an online incorporation of an SUP. Member States have to offer a registration procedure that can be completed electronically without requiring the need of a physical presence of the founder of an sup before the authorities of the Member State of registration. However, in addition to the online registration Member States may allow sups to be registered in other ways (Article 14(3)). This option is especially important for Member States that traditionally require notarial intervention for the incorporation of companies. These Member States may still offer the founder of the sup the choice between (i) online-incorporation; and (ii) incorporation by notarial deed. It is noteworthy that in the compromise text of the draft sup Directive the time at which an suP acquires legal personality is no longer linked to its (online) registration. It is left to each Member State to determine the connecting factor for the acquisition of legal personality (Article 14(2)). If the SUP is incorporated by a notarial deed, that connecting factor could be set at the time of execution of the notarial deed. We expect that this compromise will contribute to the acceptance of the SUP Directive by the Member States.

\subsection{Minimum Capital Requirement and Creditor Protection}

In the nineties of the last century the lack of a minimum capital requirement was an important incentive to incorporate a private limited liability company (ltd.) in the United Kingdom, because at that time it was the only EU Member State which made that possible. The result was that quite a lot of foreign entrepreneurs set up a ltd. in the United Kingdom while operating exclusively in the home Member State of the entrepreneurs. By doing so, the national minimum capital requirement for private companies was circumvented. This practice was allowed by the ECJ in the Centros and Inspire Art judgments. ${ }^{108}$ The ECJ considered the fact that an EU resident establishes a company in a Member

108 ECJ Case C-212/97 Centros [1999] ECR I-1459 and ECJ Case C-167/o1 Inspire Art [2003] ECR I-10155. 
State where the company law rules are quite liberal to be an inherent element of the right of establishment, and not to be an abuse of that right. These judgments led to a significant increase in the number of incorporations of ltd.'s in the United Kingdom by foreign entrepreneurs. 109

In order to make the domestic private company a more attractive company form and a more competitive one, especially in comparison with the ltd., in the following years a significant number of EU Member States lowered the minimum capital requirement or even abolished it. ${ }^{110}$ These Member States will agree with a minimum capital requirement of EUR 1 for the SUP or no requirement at all. However, in a minority of the Member States the minimum capital requirement is still set at a relatively high amount. For a German $\mathrm{GmbH}$, the minimum capital is set at EUR 25,000, although entrepreneurs have the option of setting up an UG with a minimum capital of EUR 1 (see section 2.2.3.). For a Hungarian Korlatolt Felelossegu Tarsasag (KFT) a minimum capital requirement of 3 million HUF - approximately EUR 12,000 - applies. The amount of the minimum capital for a Luxembourg SARL was recently reduced to EUR 12,000, whereas for a Slovenian Druzba z omejeno odgovornostjo (D.O.O.) the minimum capital requirement amounts to EUR 7,500 and for a Swedish Aktiebolag Privat to 50,000 Swedish kronor, a little more over EUR 5,000. These differences explain that in respect of the SPE (European Private Company), ${ }^{111}$ the minimum capital requirement was one of the three main outstanding issues on which the Council could not reach political agreement. ${ }^{112}$ The same could become true for the suP. The last-mentioned Member States will want to shape - if possible - the minimum capital requirement for the sUP in line with that for their domestic types of private company. If they accept a lower figure of minimum capital for the SUP, or even none, they take the risk that entrepreneurs will make use of the opportunity to escape the burdens of their domestic company law, and incorporate an SUP instead of a domestic type of private company.

109 See M. Becht, C. Mayer and H.F. Wagner, 'Where do firms incorporate? Deregulation and the Cost of Entry', ECGI Law Working Paper No. 70/2006, August 2007.

110 An additional argument is that minimum capital requirements significantly slow entrepreneurship. Research shows that the existence of a minimum capital requirement directly hinders business development and growth. See International Bank for Reconstruction and Development/The World Bank, 'Doing Business 2016 - Measuring Regulatory Quality and Efficiency, A World Bank Group Flagship Report'. Retrieved 3 July 2017 www.doingbusiness.org/reports/global-reports/doing-business-2016.

111 'Proposal for a Council Regulation on the Statute for a European private company' $\operatorname{com}(2008) 396 / 3$ (June 2008). This proposal has been withdrawn.

112 Interinstitutional File 2008/0130 (CNS), document 8083/11, DRS 42, SOC 275. 
The aforementioned problem will not arise in respect of creditor protection rules. According to Article 18(1) draft sup Directive it is up to the Member States to ensure that an SUP is prevented from being unable to pay its debts after making distributions to its shareholder. Following the rules for the domestic private company Member States may choose between an asset protection system with a minimum capital requirement and a balance sheet net asset test for distributions, or a system based on a combination of solvency protection and liability of the director(s) and the shareholder.

\subsection{Board Structure: Two-Tier, One-Tier or a Choice between Both}

As described in section 2.2.1., currently there are two different board structures for (public) companies in the European Union. In some Member States the two-tier board structure is mandatory, whereas in some other Member States only the one-tier board structure is available to (public) companies. However, in a significant number of Member States a public company may choose between a one-tier and a two-tier board structure. The European regulator has implemented this choice in the SE Regulation by leaving it to the founders of the SE to choose between both systems. This also applies to EU Member States where founders of a national public company do not have such a choice. In Germany and the Czech Republic, for instance, the two-tier board structure is still obligatory for a national public company. In a report on the operations and the impacts of the SE Regulation by Ernst \& Young in 2009, the fact that the SE Regulation offers the possibility of choosing between two categories of corporate governance structure is considered to be a competitive edge of the SE over the public company. ${ }^{113}$

In 2012, Stollt and Keleman presented the results of a study on the corporate governance structure of SE's in practice. ${ }^{114}$ Of the then existing 1,426 SE's, 76 percent had a two-tier board structure compared to only 17 percent with a one-tier board structure. For 7 percent of the SE's the board structure was unknown. In almost all Member States the majority of SE's had opted for the traditional national board structure. For example, in the Czech Republic 98 percent of the 901 SE's had opted for the familiar two-tier board, whereas in Germany 60 percent of the 226 SE's did so.

113 Study on the operation and the impacts of the Statute for a European Company (SE) 2008/S 144-192482 -Final report 9 December 2009, 87.

114 M. Stollt and M. Keleman, 'A big hit or a flop? A decade of facts and figures on the European Company (SE)', in: J. Cremers, M. Stollt and S. Vitols (eds), A decade of experience with the European Company (SE) (Brussels: ETUI, 2012). 
These figures show that in these Member States the new, free choice of the board structure of the SE did not lead to an overwhelming choice for the onetier board, but also that there is a certain need for a one-tier board. In our opinion, it is advisable that the European legislator, if he introduces new legal forms, provides for flexibility by giving the founder(s) the choice between both board structures. Given the experiences gained with the SE, we expect that the different board structures will no longer be a stumbling block for Member States.

\subsection{Employee Participation/Co-Determination}

EU Member States have very different views with regard to employee involvement. This is not so much the case in respect of the employee's rights of information and consultation. An EU Directive establishing a general framework for these rights has existed since 2002. ${ }^{115}$ It sets minimum principles, definitions and arrangements for information and consultation of employees at the enterprise level within each Member State. It covers the following areas: economic, financial and strategic developments; structure and foreseeable development of employment and related measures; and decisions likely to lead to substantial changes in work organisation or contractual relations. To accommodate SMEs, Directive 2002/14/EC applies only to undertakings employing at least 50 employees, or to establishments employing at least 20 employees. The choice was at each Member State's discretion. According to a review of the application of Directive 2002/14/EC in the EU executed in 2008, the large majority of Member States adopted implementing measures which cover the main elements of the Directive. ${ }^{116}$ Nevertheless, some issues raised questions of interpretation or doubts about a proper implementation. In general, however, it is accepted throughout the EU that employees have information and consultation rights at the enterprise level.

In respect of board-level employee representation (employee participation) EU-Member States have a very different outlook. One of the reasons is that while the information and consultation rights of employees are exercised at the level of the enterprise, the participation rights are exercised at the level of the legal form of the enterprise - the company. Employees or their

115 Directive 2002/14/EC of the European Parliament and of the Council of 11 March 2002 establishing a general framework for informing and consulting employees in the European Community [2002] OJ L 80/29.

116 Communication from the Commission to the Council, the European Parliament, the European Economic and Social Committee and the Committee of the Regions on the review of the application of Directive 2002/14/EC in the EU, 17 March 2008, сом(2008) 146 final. 
representatives have influence on the composition of the supervisory or the administrative board of a company through rights to elect or appoint a certain number of members of those company bodies or through rights of nomination or opposition.

In some Member States, there is quite a lot of resistance to the introduction of employee representation in the company's decision-making bodies. An exemplary recent discussion took place in the United Kingdom, with the result that the government does not intend to mandate employee representation on company's boards. ${ }^{117}$

Will these differences, in respect of employee participation, hinder the introduction of new EU legal forms of the enterprise like the SUP? Where an SUP is incorporated ex nihilo the law of the Member State of its registered office is applicable. This includes provisions in respect of board-level employee representation, if any.

However, if an SUP is incorporated by way of a cross-border conversion of an already existing private company into an SUP, the problem arises that the incorporation of the SUP could be used to circumvent the national rules in respect of employee participation. In order to prevent this, a provision that, in essence, ${ }^{118}$ is similar to the one in Directive 2005/56/EC in respect of

117 In the summer of 2016 Theresa May, at that time the next United Kingdom's Prime Minister, pleaded to put employees on the boards of companies. See e.g. www.macfarlanes .com/media/682268/employees-on-the-board-theresa-mays-next-big-idea.pdf. In the autumn of 2016, after a lot of criticism, she backtracked and told business leaders that her government would not force companies to directly appoint employees on to their boards. See e.g. A. Asthana and P. Walker, 2016. 'Theresa May: I won't force companies to appoint workers to their boards'. The Guardian, November 21. Retrieved 29 June 2017 www.theguardian.com/business/2016/nov/21/theresa-may-force-firms-appoint-workers -boards-cbi. See also the uk government's Green Paper on Corporate Governance Reform, published on 29 November 2016. Retrieved 3 July 2017 www.gov.uk/government/ consultations/corporate-governance-reform.

118 The first exception in Article 16 Directive 2005/56/EC that the converting private company has an average number of employees that exceeds 500 and is operating under an employee participation system has not been integrated in our proposal, because it excludes small companies. In Sweden, Denmark and the Netherlands, for example, a company should have an average number of employees of at least 25, 35 or 100 in order to give employees participation rights (consult www.worker-participation.eu/National-Industr ial-Relations/Countries/Sweden/Board-level-Representation; www.worker-participation .eu/National-Industrial-Relations/Countries/Denmark/Board-level-Representation and www.worker-participation.eu/National-Industrial-Relations/Countries/Netherlands/ Board-level-Representation). 
cross-border mergers ${ }^{119}$ should be introduced into the suP Directive. Also, in the case of a cross-border conversion of a private company into an SUP, the general rule is that the sup shall be subject to the rules in force in respect of board-level employee representation, if any, in the Member State where it has its registered office. However, there are two exceptions to this general rule where its application will lead to a reduction of employee participation rights. These exceptions refer to a situation that (i) the national law of the inbound Member State does not provide for at least the same level of employee participation as the outbound Member State; or (ii) that this law does not provide for the same participation rights for employees of establishments of the suP that are situated in Member States other than the Member State of the registered office of the SUP. In these two cases a procedure similar as the one in the SE Directive will apply. This means that employee participation in the forthcoming SUP is the subject of negotiations between a special negotiating body of employee representatives and the management of the converting private company. The applicability of this negotiation procedure will make the incorporation of an SUP more burdensome and time-consuming. However, we deem it inevitable in order to prevent the conversion of a private company into an sup being used in a way to circumvent national rules in respect of employee participation.

Possible European Stumbling Blocks to the Introduction of the SUP

Finally, there might be some European stumbling blocks to the introduction by the European legislator of a new legal enterprise form such as the SUP. The following subjects are considered: the legal basis for the draft sup Directive and the principles of subsidiarity and proportionality.

\subsection{Choice of the Legal Basis for the Draft sUP Directive}

Each time the European legislator purports to introduce a new legal enterprise form he has to choose its legal basis in the TFEU. The choice of the specific legal basis is decisive for the majority required in the European Council to adopt the legislative act. The draft sUP Directive is based on Article 50 T FEU, which is the legal basis for the competence of the $\mathrm{EU}$ to act in the area of harmonising company law. In particular, Article $50(2)(f) \mathrm{TFEU}$ provides for the progressive

119 Article 16 Directive 2005/56/EC (Directive 2005/56/EC of the European Parliament and of the Council of 26 October 2005 on cross-border mergers of limited liability companies [2005] OJ L 310/1). 
abolition of restrictions on the freedom of establishment as regards the conditions for setting up subsidiaries in the territories of Member States. This entails that a majority decision of the European Council suffices for the adoption of the sup Directive (Article $294 \mathrm{TFEU}$ ) and thus that (the minority of) Member States can be overruled.

However, the choice to take Article 50 TFEU as the legal basis for the SUP Directive has been criticised. Kindler points out that the European legislator, in the past, chose the 'flexibility clause' of Article $35^{2}$ TFEU for the enactment of legislation on European legal forms of the EEIG, SE and SCE. Pursuant to Article $35^{2}$ TFEU a unanimous decision by the European Council is required. Kindler argues that Article $35^{2}$ TFEU would be the proper method for the adoption of the sup Directive, because it introduces a new legal enterprise form whose regulatory density is high. ${ }^{120}$ Others, however, are of the opinion that Article 50 TFEU does provide a sufficient legal basis. They point out that the draft sup Directive does not establish a new supra-national legal form for the single member company, but rather contributes to the progressive abolition of restrictions on the freedom of establishment. ${ }^{121}$

\subsection{Subsidiarity and Proportionality Principles}

According to the principle of subsidiarity as defined in Article $5 \mathrm{TEU},{ }^{122}$ the EU does not take action (except in the areas that fall within its exclusive competence), unless it is more effective than action taken at national, regional or local level. ${ }^{123}$ For that reason, the subsidiarity aspect will only be questioned after the competence of the EU has been established. Article 50 TFEU, being the legal basis of the draft sup Directive, does not give the EU exclusive competence to regulate economic activity on the internal market, but only a certain competence for the purpose of improving the conditions for the establishment and the functioning of the internal market, in particular by eliminating restrictions on the freedom of establishment and by giving effect to this

120 Kindler, The Single-Member Limited Liability Company (n 81) 49.

121 Council of the European Union, opinion of the Legal Service of 17 October 2014, file no. 14423/14; G.J. Vossestein, 'Europees vennootschapsrecht en de besloten vennootschap' ('European company law and the private company'), Weekblad voor privaatrecht, notariaat en registratie 7030 (2014) 781.

122 See also Protocol (02) on the application of the principles of subsidiarity and proportionality, OJ C 115, 9 May 2008, 206-209.

123 See ECJ Case C-491/o1 British American Tobacco [2002] ECR I-11453, paras. 177 and 179. This case is about the competence of the EU under Article 95 EC (now Article 114 TFEU). As regards the EU'S competence under Article 50 TFEU the same applies, because both provisions serve the realisation of the internal market. 
freedom. ${ }^{124}$ Accordingly, harmonisation Directives in the field of company law must comply with the principle of subsidiarity. ${ }^{125}$ The principle of subsidiarity is closely intertwined with the principle of proportionality, which requires that any action taken by the EU should be appropriate to achieve the pursued objectives of the Treaties and not go beyond what is necessary to achieve these.

In the explanatory memorandum to the draft sup Directive the European Commission expresses its opinion that the draft sup Directive complies with both principles. ${ }^{126}$ The question is whether indeed there is a need for a European solution such as the suP for an easier and less costly way to set up private companies across the $\mathrm{EU}$ in order to achieve a higher cross-border participation of SMEs within the EU. ${ }^{127}$ In this respect the European Commission speaks of introducing into the national legal systems identical requirements for a particular national company law form. A point of criticism: harmonisation of company law is about achieving equivalent outcomes, not per se identical ones. More important, however, is the fact that already a significant number of EU Member States provides for an online incorporation procedure of capital companies (see section 4.1.). Such a procedure is accessible for residents and non-residents. In these states, it is quite easy to form an independent company or a subsidiary, also in a cross-border way. Is there a need for introducing a new EU legal enterprise form to achieve the same result in all EU Member States? In other words: is interference of the European legislator really necessary or is a bottom-up harmonisation preferable? A comparison with the minimum capital requirement is obvious. Once this became a competitive element in the

124 See G.J. Vossestein, Modernization of European Company Law and Corporate Governance, Some Considerations on its Legal Limits (Alphen aan den Rijn: Kluwer Law International, 2010) 173 .

125 See C.W.A. Timmermans, 'Is het subsidiariteitsbeginsel vatbaar voor rechterlijke controle?' ('Is the subsidiarity principle susceptible of judicial determination?'), SEW (2007) 226.

$126 \operatorname{COM}(2014) 212$ final (April 2014) $5^{-6 .}$

127 The Dutch government answered this question in a negative way. The scope of the Directive should be restricted to removing barriers for the setting up of a subsidiary in another Member State. The introduction of unified rules for a new legal form like the sup, which can also be used for pure national activities, is in conflict with the principle of subsidiarity. See Letter of the Minister of Foreign Affairs of 23 May 2014; retrieved 3 July 2017 www .eerstekamer.nl/eu/behandeling/20140523/brief_regering_fiche_richtlijn/document3/f=/ vjkdfkjhgoz5.pdf. Also, Kindler is negative. According to Kindler even without an online incorporation procedure it is possible to form a subsidiary in Germany with reasonable costs. See P. Kindler, The Single-Member Limited Liability Company (sUP) (München: C.H. Beck, 2016) 15-16. However, the question is whether this is the case in all EU Member States. 
incorporation procedure of a private company the result was that the majority of the Member States lowered the minimum capital requirement or even abolished it. It is our expectation that it will be only a matter of time before the remaining EU Member States will follow the example set and introduce an online incorporation procedure for capital companies.

Furthermore, the incorporation procedure is only one of the elements that have to be considered in order to make it easier and less costly for entrepreneurs to set up an independent company or a subsidiary in another EU Member State. There seem to be some more important barriers. In a consultation on single-member limited liability companies ${ }^{128}$ held in 2013, 47,9 percent of the respondents answered that the compliance costs with foreign legislation on company law issues (translation, registration requirements/fees, capital requirements, reporting, operational/running costs including legal advice related to it, etc.) are an important barrier to moving or expanding a commercial activity abroad. The two most important issues within these compliance costs are: annual running/operational costs including reporting, accounting, auditing, legal advice (73,1 percent) and other issues, e.g. labour law, health and safety issues (51,7 percent). This means that even after the adoption and implementation of the sup Directive only a small part of the barriers for crossborder establishments by sMEs will be removed.

The above raises questions about the subsidiarity and the proportionality aspects of the draft sup Directive. However, according to the case-law of the ECJ the limits which both principles place upon the EU legislation must not be overestimated. ${ }^{129}$ Where the objective of the legislation is to abolish restrictions raised by the differences between the national legislations, the ECJ readily accepts that such an objective cannot be sufficiently achieved by the Member States individually and that an action at the EU level is called for. ${ }^{130}$

128 Response statistics for 'Single-member limited liability companies'. Retrieved 3 July 2017 ec.europe.eu/internal_market/consultations/2013/single-member-private-companies.

129 See K.J. Hopt, Company Law in the European Union: Harmonization or Subsidiarity (Saggi, Conference e Seminari) (Rome: Centro di studi e ricerche di diritto comparato e straneiro 1998) 10; G. Davies, 'Subsidiarity: The wrong idea, in the wrong place, at the wrong time', Common Market Law Review 43 (2006) 67-68; J.A. Gutierrez Fons, The Contribution of the United States Supreme Court and the European Court of Justice in the Vertical and Horizontal Allocation of Power [2009] 222-228. Retrieved 3 July 2017 www.qmro.qmul.ac.uk/jspui/ handle $/ 123456789 / 525$.

130 See the following three cases, as mentioned by G.J. Vossestein, Modernization of European Company Law and Corporate Governance, Some Considerations on its Legal Limits (Alphen aan den Rijn: Kluwer Law International, 2010) 176: ECJ Case C-491/o1 British American Tobacco [2002] ECR I-11453, para. 182; joined Cases C-154-04 and C-155/04 Alliance for 
This condition is met with the draft sup Directive: its objective is to eliminate the restrictions on the freedom of establishment as regards the conditions for setting up independent companies and subsidiaries across the EU. Also with regard to the proportionality principle, the ECJ allows the EU legislator a wide discretion and only exercises marginal control. ${ }^{131}$ The ECJ limits itself to verifying that there is no manifest discrepancy between the means used and the aims to be achieved.

In view of the previous observations it is not likely that the legality of the suP Directive will be affected by either the subsidiarity or the proportionality principle.

\section{$6 \quad$ Final Remarks}

During the existence of the EU the differences between the Member States in respect of (the legislation concerning) legal enterprise forms have become less sharp. This is partly due to the interference of the European legislator, for example by enacting Company Law Directives which the Member States had to implement into their national legislation and by introducing supra-national, European legal forms such as the SE. Bottom-up harmonisation - not initiated by the EU legislator but sometimes the result of judgements of the ECJ - has also contributed to the removal of differences between Member States.

As regards the SUP there are - in our opinion - no irreconcilable differences between the legislations of the EU Member States that might hinder the introduction of this new legal form for a single-member private limited liability company. Also, the European principles of subsidiarity and proportionality will not constitute an obstacle. The crucial question is whether a majority of the Member States will see the economic and political necessity of the SUP so that the necessary progress will be made for the adoption of the SUP Directive. The future will tell.

natural Health a.O. [2005] ECR I-6451, paras. 105-106 and ECJ Case C-377/98 Netherlands $v$ Parliament and Council [2001] ECR I-7079, para. 32. As far as we know the ECJ has never annulled an EU measure on the ground that it is contrary to the subsidiarity principle.

131 See in particular case C-491/01 British American Tobacco [2002] ECR I-11453, paras. 123 and 184 . 